\title{
Analisis Pengaruh Fundamental Makro dan Fundamental Mikro Terhadap Struktur Kepemilikan, Kinerja Keuangan, dan Nilai Perusahaan pada Badan Usaha Milik Negara yang Terdaftar di Bursa Efek Indonesia
}

\author{
Hwihanus $^{1}$, Tri Ratnawati ${ }^{2}$, \& Indrawati Yuhertiana ${ }^{3}$ \\ ${ }^{1-2}$ Economic Faculty, University of 17 Agustus 1945 Surabaya \\ ${ }^{3}$ Economic and Business Faculty, University of Pembangunan Nasional Veteran Jawa Timur \\ 1'hwihanus@untag-sby.ac.id, 2tri.wdhidayat@yahoo.com, ${ }^{3}$ yuhertiana@gmail.com
}

\begin{abstract}
This study aims to examine and analyze the relationship between the variability of $m u$ tuality micro fundamental, macro fundamentals of ownership structure, financial performance, and the value of companies in State-Owned Enterprises listed on the Indonesia Stock Exchange. Research population at 20 State-Owned Enterprises listed on Indonesia Stock Exchange. This research method uses purposive sampling with 12 companies in 2010-2015. Data analysis of techniques in this study using Partial Least Square consists of Inner model, Outers model and Weight relation. The test results showed that all hypothesis testing was accepted which showed significant effect with 5\% level with $t$-table 1,960 and rejected macro fundamentals to firm value with $t$-statistic 0,666262 (H5) and micro fundamentals of company value with t-statistic 1,188469 (H6) and ownership structure on the financial performance of the company with $t$-statistics 0.953625 (H7).
\end{abstract}

Keywords: macro fundamental, micro fundamental, ownership structure, financial performance, value of the firm

\section{PENDAHULUAN}

Peneliti tertarik mengamati Badan Usaha Milik Negara (BUMN) yang memiliki prospek prospektif bagi para investor dibandingkan perusahaan swasta terutama harga saham BUMN dan Indeks Harga Saham Gabungan (IHSG) di pasar modal yang berfluktuasi sesuai dengan kondisi ekonomi negara dan keputusan pemerintah yang memberikan sentimen bagi pasar saham.

Harga saham mewakili nilai perusahaan yang ditentukan oleh faktor internal dan eksternal perusahaan. Faktor internal dan eksternal merupakan faktor fundamental yang sering digunakan sebagai dasar oleh investor di pasar modal untuk membuat keputusan investasi (Pater et al. 2014). Selain faktor fundamental, faktor teknis juga merupakan faktor penting yang dapat memengaruhi harga saham yang bersifat teknis dan psikologis.
Perusahaan yang tergabung termasuk BUMN memiliki tujuan dalam mengoptimalkan nilai perusahaan yang tecermin dalam kesejahteraan para pemilik. Jika semakin tinggi nilai tecermin dalam harga pasar saham, memberikan kemakmuran kepada pemilik (Fama, 1978, McConnell dan Muscarela, 1985). Penyatuan kepentingan pemegang saham, pemegang utang, dan manajemen yang notabene adalah pihak-pihak yang memiliki kepentingan terhadap tujuan perusahaan yang sering menimbulkan masalah (agency problem) atau konflik kepentingan yang dikenal sebagai agency theory (Jensen dan Meckling, 1976).

Beberapa peneliti percaya bahwa struktur kepemilikan dapat memengaruhi cara perusahaan pada akhirnya memengaruhi kinerja perusahaan dalam mencapai tujuan perusahaan dan memaksimalkan nilai perusahaan (Khlif et al., 2015; Farooque et al., 2010). 
Peningkatan nilai perusahaan sebagai tujuan kesejahteraan pemegang saham untuk kinerja keuangan perusahaan dalam mengelola operasi organisasi secara efektif dan efisien untuk pengambilan keputusan. Nilai maksimum perusahaan dihasilkan dari struktur kepemilikan dan kinerja keuangan suatu perusahaan berdasarkan makro dan mikro fundamental.

\section{TINJAUAN LITERATUR}

\section{Akuntansi Manajemen}

Akuntansi manajemen adalah sistem akuntansi yang memiliki hubungan dengan ketentuan dan penggunaan informasi manajemen dalam suatu organisasi. Akuntansi manajemen bertujuan untuk memberikan patokan kepada manajemen dalam pengambilan keputusan bisnis, mengelola dan melakukan fungsi pengawasan atas hasil yang telah diperoleh perusahaan. Akuntansi manajemen membantu persiapan perencanaan yang efektif sebagai suatu pelanggaran, membantu proses pengawasan dan kontrol dan membantu mengatasi masalah yang berkaitan dengan penyimpangan dalam perusahaan.

\section{Teori Agensi}

Jensen dan Meckling (1976) berpendapat bahwa pemilik sebagai prinsipal dan manajemen sebagai penerima otoritas memiliki kepentingan yang berbeda dalam hubungan kerja. Pemilik menginginkan pengembalian investasi secara maksimal sesegera mungkin, sementara manajemen menginginkan agar kepentingannya dapat ditampung sebanyak mungkin atas kinerja yang telah dilakukan.

Konflik kepentingan antara agen dan prinsip dalam mencapai kemakmuran dapat terjadi dari adanya asimetri informasi. Ini memberikan ke- sempatan bagi manajer untuk memanipulasi pelaporan keuangan dalam upaya untuk memaksimalkan kemakmuran mereka (Cheng et al. 2012, Wasiuzzaman, 2015).

\section{Faktor Fundamental Makro}

Faktor makro mendasar yang berasal dari luar perusahaan dapat berupa ekonomi, lingkungan, politik, hukum, sosial, budaya, keamanan, pendidikan, dan lain-lain yang tidak dapat dikendalikan oleh perusahaan tetapi efeknya sangat besar untuk perubahan dalam memutuskan untuk berinvestasi (Claude et al. 1996). Fundamental makro berupa tingkat suku bunga bank Indonesia, pendapatan domestik bruto, inflasi dan nilai tukar mata uang asing dollar Amerika terhadap Indonesia yang terjadi.

\section{Faktor Fundamental Mikro}

Faktor fundamental mikro berasal dari dalam perusahaan dan mengendalikan serta digunakan dalam perkembangan perusahaan di masa depan. Pengembangan perusahaan ini khususnya manajemen membutuhkan beberapa kebijakan dalam kegiatan operasional perusahaan yaitu keputusan investasi, keputusan pendanaan, dan kebijakan dividen.

\section{Struktur Kepemilikan}

Struktur kepemilikan adalah persentase kepemilikan saham suatu perusahaan yang dapat mencerminkan distribusi kekuasaan dan pengaruh atas kegiatan operasional perusahaan. Struktur kepemilikan dapat dilihat dari pendekatan agen dan pendekatan informasi asimetris. Pendekatan agen, struktur kepemilikan sebagai mekanisme untuk mengurangi konflik kepentingan antara manajer dan pemegang saham. Pendekatan 
informasi asimetris mempertimbangkan mekanisme struktur kepemilikan sebagai sarana untuk mengurangi ketidakseimbangan informasi antara orang dalam dan orang luar melalui pengungkapan informasi dalam pasar modal.

\section{Kinerja Keuangan}

Bagi perusahaan, mempertahankan dan meningkatkan kinerja keuangan adalah kebutuhan perusahaan masih ada dan diminati oleh investor sebagaimana tecermin dalam laporan keuangan tingkat likuiditas, profitabilitas dan leverage dalam pengambilan keputusan dan menciptakan nilai perusahaan.

\section{Nilai Perusahaan}

Nilai buku dalam laporan keuangan adalah batasan mengukur nilai perusahaan dengan menggunakan persepsi harga saham. Tujuan utama perusahaan (Sirmon et.al. 2007) adalah untuk memaksimalkan nilai perusahaan dengan arti yang lebih luas, tidak hanya untuk memaksimalkan laba perusahaan tetapi untuk mempertimbangkan efek waktu pada nilai uang, untuk mempertimbangkan berbagai risiko terhadap aliran pendapatan perusahaan dan kualitas arus kas yang diharapkan di masa depan. Nilai perusahaan sebagai nilai pasar saham (Bowman dan Ambrosini, 2007), yang dapat memberikan kekayaan pemegang saham maksimum jika harga saham perusahaan meningkat.

\section{Hipotesis Penelitian}

Hipotesis penelitian dapat dilakukan sebagai berikut.

1. Fundamental makro memiliki pengaruh yang signifikan terhadap struktur kepemilikan.

2. Fundamental mikro memiliki pengaruh yang signifikan terhadap kinerja keuangan.
3. Makro fundamental memiliki pengaruh yang signifikan terhadap kinerja keuangan.

4. Fundamental mikro memiliki pengaruh yang signifikan terhadap struktur kepemilikan.

5. Makro fundamental secara signifikan memengaruhi nilai perusahaan.

6. Fundamental mikro memiliki pengaruh yang signifikan terhadap nilai perusahaan.

7. Struktur kepemilikan memiliki pengaruh yang signifikan terhadap kinerja keuangan.

8. Struktur kepemilikan memiliki pengaruh yang signifikan terhadap nilai perusahaan.

9. Kinerja keuangan memiliki pengaruh yang signifikan terhadap nilai perusahaan.

\section{METODE PENELITIAN}

\section{Sampel Penelitian}

Teknik pengambilan sampel menggunakan metode purposive sampling dengan 12 dari 20 BUMN yang terdaftar di Bursa Efek Indonesia dengan periode pengamatan 2010-2016.

\section{Variabel dan Indikator}

Variabel dan indikator yang digunakan dalam penelitian ini adalah sebagai berikut.

Tabel 1 Variabel, Notasi, dan Indikator Penelitian

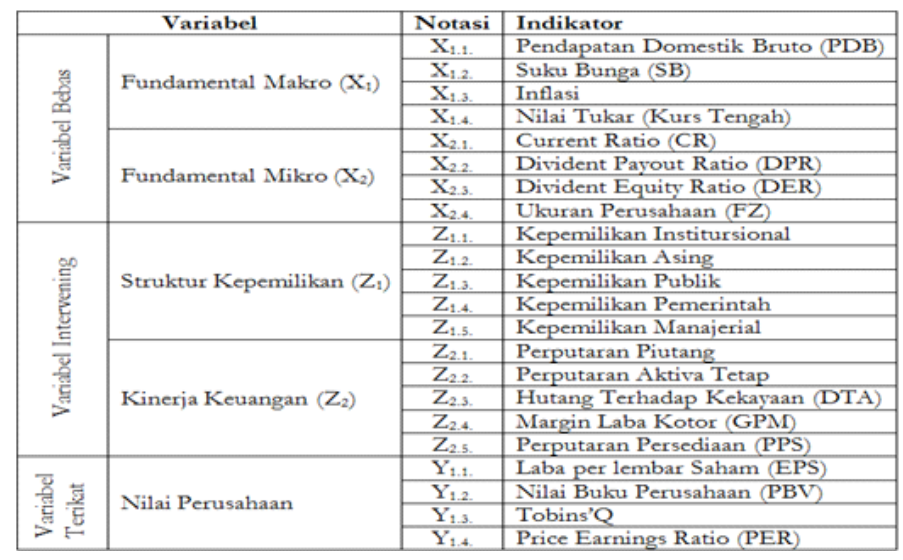

Sumber: data diproses 


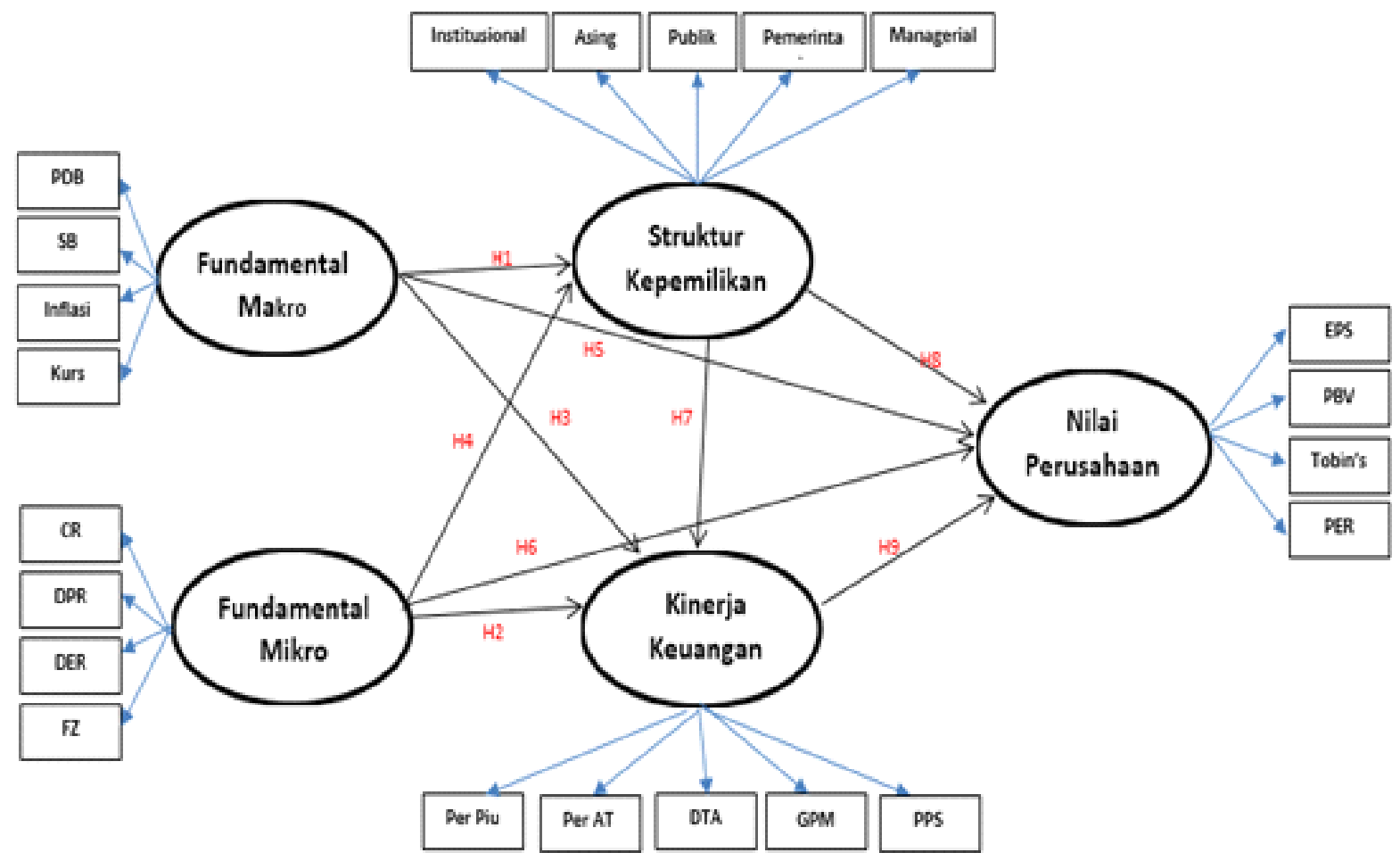

Gambar 1 Kerangka Kerja Konseptual

\section{Kerangka Konseptual}

Hubungan antara variabel penelitian dapat dijelaskan kerangka kerja konseptual pada Gambar 1.

\section{ANALISIS DAN PEMBAHASAN}

\section{Uji Model Penelitian}

Penelitian ini menggunakan faktor pembatas faktor pembebanan dengan merefleksikan indi-

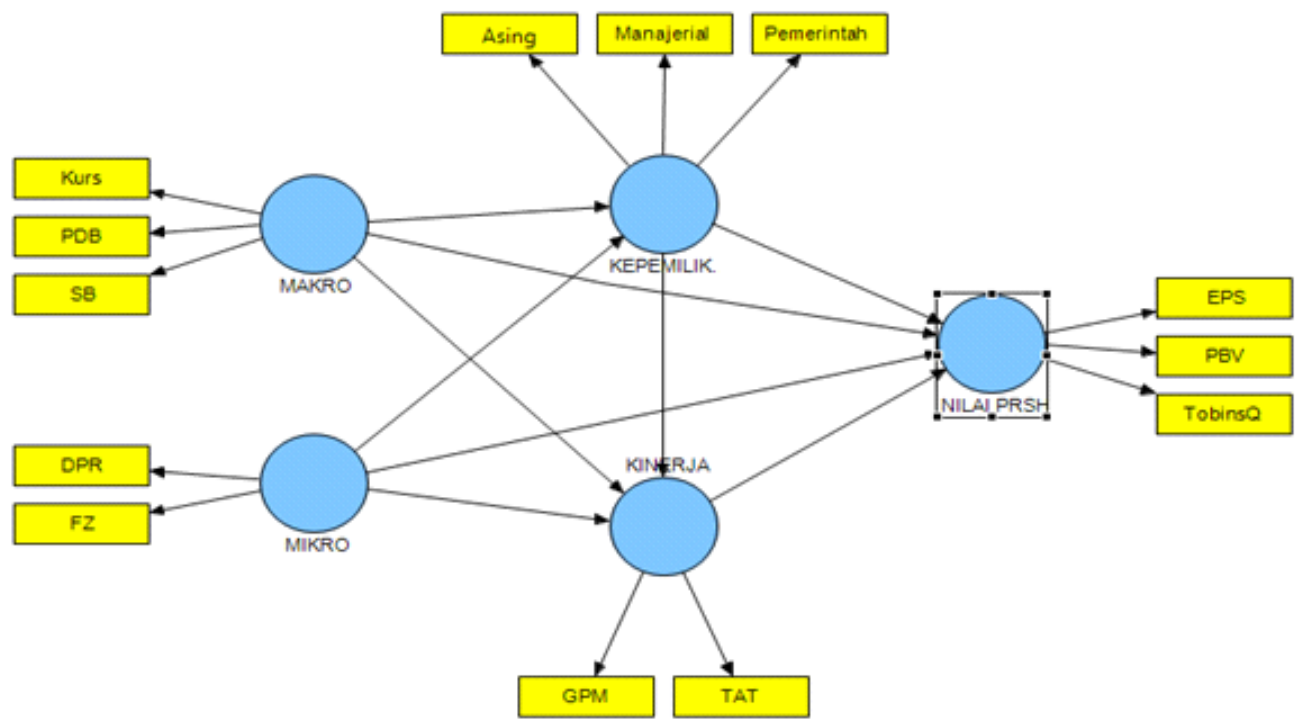

Sumber: Olahan Data

Gambar 2 Hasil Uji Model Struktural (Inner Model) 
kator berdasarkan hubungan antara masingmasing item skor dengan skor konstruksinya dengan skala pengukuran yang dirasakan cukup pada nilai pembebanan 0,5 sehingga skala pengukuran yang tidak memenuhi ketentuan dari menjatuhkan. Hasil tes model dalam dapat ditunjukkan pada Gambar 2.

Uji statistik dalam hubungan antar-variabel membutuhkan tingkat signifikansi 95\% $(\alpha=$ $0,05)$ dan nilai t-tabel adalah 1,96 untuk menerima hipotesis alternatif. Hasil pengujian hipotesis secara keseluruhan dapat dilihat pada Tabel 2.

Tabel 2 Hasil Pengujian Hipotesis

\begin{tabular}{|c|c|c|c|c|c|c|c|}
\hline $\mathrm{Ha}$ & Relationship Variable & $\begin{array}{l}\text { Original } \\
\text { Sample } \\
(0)\end{array}$ & $\begin{array}{l}\text { Sample } \\
\text { Mean } \\
(\mathrm{M})\end{array}$ & $\begin{array}{c}\text { Standard } \\
\text { Devia } \\
\text { tion } \\
\text { (SID } \\
\text { EV) }\end{array}$ & $\begin{array}{r}\text { Standard } \\
\text { Error } \\
\text { (STE } \\
\text { RR) }\end{array}$ & $\begin{array}{c}\text { T Statistics } \\
(0 / S T E \\
\text { RR })\end{array}$ & Significant \\
\hline $\mathrm{Hl}$ & makro -> kepemilikan & $-0,047953$ & $-0,048980$ & 0,022295 & 0,022295 & 2,150872 & Signifikan \\
\hline $\mathrm{H} 2$ & mikro -> kinerja & 0,660956 & 0,662105 & 0,016104 & 0,016104 & 41,042109 & Significant \\
\hline $\mathrm{H}_{3}$ & makro -> kinerja & $-0,114181$ & $-0,118162$ & 0,020066 & 0,020066 & 5,690303 & Significant \\
\hline $\mathrm{H} 4$ & mikro -> kepemilikan & $-0,360660$ & .0 .357358 & 0,019950 & 0,019950 & 18,078276 & Significant \\
\hline H5 & makro-> nilai prsh & $-0,018069$ & $-0,022109$ & 0,027120 & 0,027120 & 0,666262 & Not Significant \\
\hline $\mathrm{H} 6$ & mikro -> nilai prsh & 0,025162 & 0,025280 & 0,021172 & 0,021172 & 1,188469 & Not Significant \\
\hline H7 & kepemilikan-> kinerja & $-0,023039$ & $-0,025561$ & 0,024159 & 0,024159 & 0,953625 & Not Significant \\
\hline $\mathrm{H} 8$ & kepemilikan $>>$ nilai prsh & $-0,277382$ & $-0,277271$ & 0,013424 & 0,013424 & 20,663599 & Significant \\
\hline $\mathrm{H} 9$ & kinerja $->$ nilai prsh & 0,416881 & 0,418045 & 0,018732 & 0,018732 & 22,254436 & Significant \\
\hline
\end{tabular}

\section{Pembahasan}

Hasil hipotesis dan hubungan antar variabel dalam Badan Usaha Milik Negara yang terdaftar di Bursa Efek Indonesia dengan observasi mulai tahun 2010 hingga 2015 adalah sebagai berikut.

Fundamental makro dengan nilai tukar mata uang asing, suku bunga dan produk domestik bruto memiliki pengaruh negatif dan signifikan terhadap struktur kepemilikan dengan indikator kepemilikan pemerintah, asing dan manajerial.

Fundamental mikro dengan indikator DPR dan FZ memiliki pengaruh positif dan signifikan terhadap kinerja keuangan dengan indikator GPM dan perputaran aktiva tetap. Penelitian ini berbeda dengan penelitian Hardaningtyas (2014) yang menghubungkan fundamental mikro dengan harga saham, sementara peneliti membahas pengaruh fundamental mikro terhadap kinerja keuangan di BUMN.

Fundamental makro memiliki pengaruh negatif dan signifikan terhadap kinerja keuangan, peraturan pemerintah dalam fundamental makro memberikan tekanan pada perusahaan dan menghasilkan kinerja keuangan. Peneliti menolak penelitian Claude, et al (1996) dan Eduardus (1997) yang menyatakan bahwa faktor fundamental makro merupakan faktor yang sangat penting berkaitan dengan kinerja dan nilai perusahaan. Para peneliti juga menerima studi Opod (2015) bahwa inflasi, suku bunga, nilai tukar, pertumbuhan ekonomi tidak berpengaruh signifikan terhadap kinerja.

Fundamental mikro dengan DPR dan indikator ukuran perusahaan memiliki pengaruh negatif dan signifikan terhadap struktur kepemilikan yang dimiliki oleh asing, manajerial dan pemerintah.

Fundamental makro memiliki efek negatif dan tidak signifikan terhadap indikator nilai tukar valuta asing dan PDB akan meningkatkan nilai perusahaan pada EPS, PBV dan Tobin's Q. Peneliti menolak penelitian Claude et al (1996) dan Eduardus (1997) menunjukkan bahwa macro fundamental faktor memiliki pengaruh positif dan signifikan terhadap nilai perusahaan.

Fundamental mikro dengan DPR dan ukuran perusahaan indikator memiliki efek positif dan tidak signifikan pada nilai perusahaan dengan EPS, PBV dan Tobin's Q. Peneliti menolak penelitian Putra (2014) untuk menunjukkan EPS dan DER berpengaruh pada nilai perusahaan. Peneliti menerima studi tentang Arvianto et al. (2014) yang menyatakan bahwa faktor fundamental mikro berpengaruh signifikan terhadap nilai perusahaan dengan kondisi faktor fundamental perusahaan memberikan pengaruh yang kuat terhadap nilai perusahaan. 
Struktur Kepemilikan saham asing, manajerial dan milik pemerintah memiliki pengaruh negatif dan tidak signifikan terhadap kinerja keuangan. Peneliti ini menolak penelitian Wahyudi dan Pawesti (2006) yang menyatakan bahwa struktur kepemilikan diyakini dapat memengaruhi bisnis perusahaan yang pada akhirnya memengaruhi kinerja perusahaan dalam mencapai tujuan perusahaan untuk memaksimalkan nilai perusahaan.

Struktur kepemilikan memiliki pengaruh negatif dan signifikan terhadap nilai perusahaan. Peneliti menolak Sugiharto et al. (2016) menunjukkan bahwa kepemilikan manajerial memiliki pengaruh positif dan signifikan terhadap nilai perusahaan.

Kinerja keuangan dengan indikator GPM dan perputaran aktiva tetap memiliki pengaruh positif dan signifikan terhadap nilai perusahaan dalam bentuk EPS, PBV dan Tobin's Q akan meningkat. Peneliti menerima studi Ukhriyawati et al. (2017) dan Dwipartha et al. (2013), yang menunjukkan kinerja keuangan nilai perusahaan memiliki pengaruh positif dan signifikan.

\section{Implikasi Teoretis}

Tujuan perusahaan adalah untuk meningkatkan laba bersih yang dihasilkan dari kegiatan operasional termasuk BUMN dengan mengoptimalkan nilai perusahaan dan kesejahteraan pemegang saham. Harga saham mewakili nilai perusahaan. Faktor internal dan faktor eksternal yang sering digunakan sebagai dasar bagi investor di pasar modal dalam mengambil keputusan investasi.

Memaksimalkan nilai perusahaan dipengaruhi oleh kontrol manajemen yang mengatur aktivitas perusahaan dalam membayar dividen atas laba perusahaan. Penentuan nilai perusahaan dipengaruhi oleh struktur kepemilikan faktor dan faktor kinerja keuangan dan beberapa faktor lain di luar objek penelitian.

\section{Implikasi Manajerial}

Eksposur ekonomi memberikan pengaruh terhadap struktur kepemilikan di mana pemerintah sebagai pemegang kontrol negara dapat menentukan kebijakan dan peran untuk BUMN dalam kesejahteraan Indonesia sesuai dengan tujuan didirikan BUMN.

\section{DAFTAR RUJUKAN}

Arvianto. Rivan Andrie Sabi. Suhadak dan Topowijono. 2014. Pengaruh Faktor Fundamental Makro dan Mikro Terhadap Nilai Perusahaan (Studi pada Saham Perusahaan Sektor Perdagangan, Jasa, dan Investiasi yang Terdaftar di BEI Periode 2010-2012). Jurnal Administrasi Bisnis (JAB), Vol. 13, No. 1 Agustus 2014, Hal. 1-10.

Bowman, Cliff and Veronique Ambrosini. 2007. Firm Value Creation and Levels of Strategy. Management Decision, Vol. 45, No. 3, pp. 360-371.

Cheng, C.S. Agnes., Bong-Soo Lee, and Simon Yang. 2012. the Value Relevance of Earnings Levels in the Return-Earnings Relation. International Journal of Accounting and Information Management, Vol. 21, Issue 4, pp. 260-284.

Claude B. Erb., Campbell R. Harvey, and Tadas E. Viskanta. 1996. Political Risk, Economic Risk, and Financial Risk, Financial Analysis Journal, Nov-Dec, pp. 29-46.

Dwipartha, Ni Made Witha. 2013. Pengaruh Faktor Ekonomi Makro dan Kinerja Keuangan Terhadap Nilai Perusahaan Manu- 
Hwihanus, Tri Ratnawati, \& Indrawati Yuhertiana, Analisis Pengaruh Fundamental Makro dan Fundamental Mikro Terhadap Struktur Kepemilikan, Kinerja Keuangan, dan Nilai Perusahaan pada BUMN

faktur di Bursa Efek Indonesia. E-Jurnal Ekonomi dan Bisnis Universitas Udayana, Vol. 02, No. 04, Pp. 226-248.

Eduardus Tandelilin. 1997. Determinants of Systematic Risk: The Experience of Some Indonesian Common Stock, Kelola, Gadjah Mada University Business Review, No. 16/ VI/1997.

Fama, Eugene F. 1978. The Effect of a Firm Investment and Financing Decision on the Welfare of Its Security Holders. American Economic Review, Vol. 68, pp. 272280.

Farooque, Omar Al., Tony van Zijl, Keitha Dunstan, and Akm Waresul Karim. 2010. Co-Deterministic Relationship between Ownership Concentration and Corporate Performance: Evidence from an Emerging Economy. Accounting Research Journal, Vol. 23, Issue 2, pp. 172-189.

Hardaningtyas, Prihati dan Khuzaini. 2014. Pengaruh Faktor Fundamental Mikro Makro Terhadap Harga Saham Perusahaan Semen Go Public. Jurnal Ilmu \& Riset Manajemen, Vol. 3, No. 10, Hal. 1-16.

Jensen, M.C. and W.H. Meckling. 1976. Theory of the Firm: Managerial Behavior, Agency Costs and Ownership Structure. Journal of Financial Economics, Vol. 13, pp. 305360.

Khlif, Hichem. 2015. Khaled Samaha and Islam Azzam. Disclosure, Ownership Structure, Earnings Announcement Lag and Cost of Equity Capital in Emerging Markets: The Case of the Egyptian Stock Exchange. Journal of Applied Accounting Research, Vol. 16, Issue 1, pp. 28-57.

McConnell, John J. and Chris J. Muscarela. 1985. Corporate Capital Expenditure Decisions and the Market Value of the Firm.
Journal of Financial Economics 14, 1985, pp. 399-422.

Opod, Chrisna Riane. 2015. Analisis Pengaruh Faktor-Faktor Fundamental Makroekonomi Terhadap Kinerja Keuangan Perusahaan serta Nilai Perusahaan (Studi Kasus pada Perusahaan Perbankan yang Terdaftar di BEI Periode 2009-2013). Jurnal Riset Bisnis dan Manajemen, Vol. 3, No. 2, 2015:127140.

Pater, Andrew Darminto dan Muhammad Saifi. 2014. Faktor Internal dan Eksternal yang Mempengaruhi Pergerakan Harga Saham (Studi Pada Saham-Saham Indeks LQ45 Periode 2009-2013). Jurnal Administrasi Bisnis (JAB), Vol. 11, No. 1, Juni 2014.

Putra, Nyoman Wedana Adi. 2014. Pengaruh Faktor Fundamental pada Nilai Perusahaan Sektor Telekomunikasi di Bursa Efek Indonesia. E-Jurnal Akuntansi Universitas Udayana, 8.3:385-407.

Sirmon, David G., Michael A. Hitt, and R. Duane Ireland. 2007. Managing Firm Resources in Dynamic Environments to Create Value: Looking Inside the Black Box. Academy of Management Review, Vol. 32, No. 1, pp. 273-292.

Sugiharto, Tri Ratnawati dan Srie Hartutie Moehaditoyo. 2016. Risk Management Mediates the Influence of Good Corporate Governance, Managerial Shareholder, and Leverage on Firm Value. IOSR Journal of Business and Management (IOSR-JBM), EISSN 2278-478X p-ISSN 2319-7668, Vol. 18. Issue 11, Ver. VI (November 2016), Pp. 62-70.

Ukhriyawati, Catur F. Tri Ratnawati, dan Slamet Riyadi. 2017. The Influence of Asset Structure, Capital Structure, Risk Management and Good Corporate Governance 
of Financial Performance and Value of the Firm through Earnings and Free Cash Flow as an Intervening Variable in Banking Companies Listed in Indonesia Stock Exchange. International Journal of Business and Management, Vol. 12, No.8, ISSN 1833-3850, E-ISSN 1833-8119, Pp. 249260.
Wahyudi, U. dan Prawesti, HP. 2006. Implikasi Kepemilikan Terhadap Nilai Perusahaan dengan Keputusan Keuangan sebagai Variabel Intervening, 23-26. SNA Padang. Wasiuzzaman, Shaista. (2015). Working Capital and Firm Value in an Emerging Market. International Journal of Managerial Finance, Vol. 11, Issue 1, 2015, pp. 60-79. 